\title{
Metabolomic Biomarkers in Anxiety Disorders
}

\author{
Elke Humer * ${ }^{\circ}$, Christoph Pieh $(\mathbb{1}$ and Thomas Probst [
}

Department for Psychotherapy and Biopsychosocial Health, Danube University Krems, 3500 Krems, Austria; christoph.pieh@donau-uni.ac.at (C.P.); thomas.probst@donau-uni.ac.at (T.P.)

* Correspondence: elke.humer@donau-uni.ac.at; Tel.: +43-2732-893-2676

Received: 26 June 2020; Accepted: 5 July 2020; Published: 6 July 2020

\begin{abstract}
Anxiety disorders range among the most prevalent psychiatric disorders and belong to the leading disorders in the study of the total global burden of disease. Anxiety disorders are complex conditions, with not fully understood etiological mechanisms. Numerous factors, including psychological, genetic, biological, and chemical factors, are thought to be involved in their etiology. Although the diagnosis of anxiety disorders is constantly evolving, diagnostic manuals rely on symptom lists, not on objective biomarkers and treatment effects are small to moderate. The underlying biological factors that drive anxiety disorders may be better suited to serve as biomarkers for guiding personalized medicine, as they are objective and can be measured externally. Therefore, the incorporation of novel biomarkers into current clinical methods might help to generate a classification system for anxiety disorders that can be linked to the underlying dysfunctional pathways. The study of metabolites (metabolomics) in a large-scale manner shows potential for disease diagnosis, for stratification of patients in a heterogeneous patient population, for monitoring therapeutic efficacy and disease progression, and for defining therapeutic targets. All of these are important properties for anxiety disorders, which is a multifactorial condition not involving a single-gene mutation. This review summarizes recent investigations on metabolomics studies in anxiety disorders.
\end{abstract}

Keywords: metabolomics; metabolites; anxiety; biomarkers

\section{Introduction}

Anxiety disorders are a prevalent global health problem, affecting the lives of almost 300 million individuals suffering from a range of anxiety disorders as well as society as a whole [1]. Anxiety disorders are currently the most prevalent psychiatric disorder in the United States and Europe and are ranked by the $\mathrm{WHO}$ as the sixth largest cause of disability worldwide and range among the top ten causes of years lived with disability [1,2]. Anxiety disorders also lead to the subsequent development of other psychiatric comorbidities, such as depression [3]. The prevalence of anxiety disorders is affected by gender, with a higher prevalence in women than men [4]. Despite a trend towards lower prevalence among older people ( $\geq 80$ years), prevalence rates are similar among age groups $[1,5]$. The group of anxiety disorders is characterized by feelings of anxiety and fear and related behavioral disturbances, such as avoidance behavior [6]. Due to the typically long-lasting duration of the symptoms experienced by affected individuals, anxiety disorders represent more chronic-recurrent than an episodic disorder [7].

Like all psychiatric disorders, anxiety disorders are diagnosed not on objective biomarkers, but based on symptom lists, which refer to a single diagnosis, while patients commonly present symptoms that fit multiple diagnoses [2]. The heterogeneous nature of the population of anxious patients does not only impede diagnosis and discovery of the underlying etiological mechanisms [8], but also contributes to the poor treatment response experienced in many patients $[9,10]$. Although 
several established psychotherapeutic and medication-based treatments exist which are effective on average [11-13], individual responses to treatments vary widely $[9,10]$, limiting the validity of assumptions that there is a single biological disturbance underlying anxiety in all patients [14,15]. Therefore, disturbances more likely differ among individuals [16], thus requiring the identification of a broader array of biomarkers to gain better insights into patient-specific etiological mechanisms that lead to more targeted treatments [17].

The inclusion of biomarkers that could help improve diagnosis might also help to generate a classification system for psychiatric disorders that can be associated with the dysfunctional pathways underpinning them, finally enabling more targeted treatments of anxiety disorders $[16,18]$. Among potential biomarkers, the study of metabolites (metabolomics) in a large-scale manner is currently regarded as one of the most informative representations of biological functions, as these molecules carry out or respond to most processes of the body $[19,20]$. More detailed information on the use of metabolomics in the study of psychiatric disorders is summarized in the following chapter.

\section{Metabolomics in Studies in Psychiatry}

Recent advances in analytical technology enable the so-called "omics technologies", referring to bioinformatics studies on genes, transcripts, proteins, and metabolites [21,22]. Among these technologies, the study of the metabolome represents the "ome", which is closest to the phenotype [23]. The word "metabolome" refers to the total metabolite pool in a cell, tissue, or organism [24]. As such, the metabolome consists of a diverse array of biomolecules that are the final products of interactions between gene expression, protein function, and the cellular environment [25]. Metabolites represent the final products and by-products of complex biosynthetic and catabolism pathways. Thus, the study of metabolites in a large-scale manner represents a powerful technique to elaborate phenotypic changes caused by exogenous stimuli more predictively than other omics technologies [24-26].

Metabolomics aims to provide detailed and mechanistic insights into the pathology of diseases by revealing altered metabolic pathways. As such, metabolomics is considered to hold potential for the identification of pathways involved in the pathophysiology of diseases and for the diagnosis of psychiatric illnesses [27,28]. Moreover, it offers new options for stratification of patients in a heterogeneous patient population, for monitoring therapeutic efficacy and disease progression, and for defining therapeutic targets [27,28]. All of these aspects have a particular value in complex pathological states, such as psychiatric disorders, as almost all of them are multifactorial conditions, not involving a single-gene mutation [29]. To sum up, metabolomics presents a tool to explore the mechanisms of diseases from a holistic perspective [29]. Therefore, metabolite profiling seems promising to recognize early biochemical changes in disease and, thus, provides an opportunity to develop predictive biomarkers that can initiate earlier interventions [30,31]. The latest applications of metabolomics cover various areas, including screening and diagnostic approaches, discovery and development of new therapeutics, evaluation of drug toxicity and assessment of therapeutic efficacy, patient stratification, and monitoring of patient response to treatment $[19,30,31]$. Thus, in the future, metabolomics might help to reveal the biological bases of psychiatric symptoms and implement personalized care to patients with mental disorders [32].

Studies based on metabolomic approaches attempt to ascertain biomarkers for diagnosis, disease progression, and the treatment response. Advanced metabolomic platforms enable a global and integrated evaluation of biochemical pathways and metabolic changes appearing in a diseased state [20]. In this regard, the most relevant biological material for the in vivo study of the pathogenesis of psychiatric disorders arguably derives from the brain [33]. Brain tissues, as well as cerebrospinal fluid-which also reflects the metabolic status and biochemistry of the brain-are the most relevant sampling substrates for identifying biomarkers of psychiatric diseases. These brain-derived samples enable the study of causal links between a detected psychiatric pathology and affected molecular pathways. However, such samples from humans are typically only available for analysis at autopsy [20]. Therefore, often animal models are used as tools that help to understand the pathogenesis of psychiatric 
disorders, as recently reviewed [34]. In humans, however, the use of plasma, serum, or urine has increased in the metabolomic study of mental disorders, which also provides valuable information about the biological signatures of psychiatric disorders. This corroborates to the whole-body concept of psychiatry, based on the fact that although psychiatric disorders seem to be generated in the brain, the effects of these illnesses can be observed throughout the body, as the brain is integrated into virtually all physiological functions of the whole body [20].

Metabolomic studies have already been reported for several psychiatric disorders, including depressive disorders, bipolar disorder, schizophrenia, and drug addiction [19,35]. However, fewer studies have been carried out in anxiety disorders. The following chapters summarize studies on the use of metabolomic platforms to reveal abnormalities and metabolic changes occurring in anxiety disorders. In addition, studies on changes in metabolites due to the treatment of anxiety disorders are summarized. To give a broader overview on changes in blood metabolites, the review is not only limited to advanced metabolomic platforms but also considers studies investigating a smaller set of metabolites by classical methods, such as photometric assays, high-performance liquid chromatography, or gas chromatography.

Therefore, a literature search was conducted using Scopus, PubMed, and APA Psycinfo databases. Research articles in scientific journals on experiments using animal models or human subjects were considered. The search was conducted on 29 May 2020, with no limitations on the publication date. Articles were identified by searching for titles using the following search terms: "(metabolom* OR metabolite OR lipidom OR lipid* OR biomarker) AND (anxi*)". The search returned 170 records after duplicates were removed.

\section{Metabolomics to Differentiate Healthy and Anxiety Subjects}

As the diagnosis of anxiety disorders still relies rather on symptom checklists than on empirical objective laboratory analyses, efforts have been made to differentiate healthy from anxious subjects by the analysis of metabolites as summarized in Table 1. Anxiety disorders are complex conditions. Numerous factors, including genetic, neurobiological, neurochemical, and psychological factors, are thought to be involved in their development [3]. To elucidate the pathways affected by anxiety disorders, and to identify possible biomarkers, animal studies using brain tissue were conducted. For more detailed information regarding the design of animal studies to serve as models for human anxiety disorders, we refer to our previous review article [34]. In brief, oxidative stress, alterations in lipid and energy metabolism (i.e., mitochondrial regulation), glutamine metabolism, and neurotransmission [36] seem to be involved in anxiety disorders. This overlaps with depressive disorders-which often occur comorbid in individuals with anxiety disorders-where changes in the glutamate-glutamine cycle, as well as changes in lipid and energy metabolism, have also been found to be related to the pathogenesis of major depressive disorder [30].

Table 1. Possible biomarkers identified to differentiate healthy and anxiety subjects.

\begin{tabular}{ccccc}
\hline Subject & $\begin{array}{c}\text { Sampling } \\
\text { Material }\end{array}$ & $\begin{array}{c}\text { Analytical } \\
\text { Platform }\end{array}$ & Metabolites Identified & Pathways Involved/Functions \\
\hline Mice & Plasma & GC-MS ${ }^{1}$ & $\begin{array}{c}\text { Myo-inositol, glutamate, } \\
\text { tricarboxylic } \\
\text { cycle-intermediates }\end{array}$ & $\begin{array}{c}\text { Mitochondrial energy pathways, } \\
\text { inositol pathways, HPA }{ }^{2} \text {-axis, } \\
\text { glutamate metabolism }\end{array}$ \\
\hline Mice & Brain & GC-MS & $\begin{array}{c}\text { Dehydroascorbate, xylose, } \\
\text { succinic acid }\end{array}$ & $\begin{array}{c}\text { Energy metabolism, } \\
\text { mitochondrial import and } \\
\text { transport, oxidative stress, } \\
\text { neurotransmission }\end{array}$ \\
\hline Mice & $\begin{array}{c}\text { Brain and } \\
\text { plasma }\end{array}$ & LC-MS/MS ${ }^{3}$ & $\begin{array}{c}\text { 1-methyl histidine, } \\
\text { deoxyuridine, kynurenic acid, } \\
\text { 2-hydroxygluterate, carnitine, } \\
\text { acetylcarnitine, cytosine }\end{array}$ & $\begin{array}{c}\text { Oxidative stress, energy } \\
\text { metabolism, amino acid } \\
\text { metabolism neurotransmitter } \\
\text { metabolism }\end{array}$ \\
\hline
\end{tabular}


Table 1. Cont.

\begin{tabular}{ccccc}
\hline Subject & $\begin{array}{c}\text { Sampling } \\
\text { Material }\end{array}$ & $\begin{array}{c}\text { Analytical } \\
\text { Platform }\end{array}$ & Metabolites Identified & Pathways Involved/Functions \\
\hline Dogs & Plasma & LC-MS 4 & $\begin{array}{c}\text { Glutamine, } \\
\gamma \text {-glutamyl-glutamine }\end{array}$ & Glutamine metabolism \\
\hline Humans & Plasma & LC-MS/MS & $\begin{array}{c}\text { Phosphatidyl-cholines (PC O } \\
\text { 36:4), ceramides (CER 20:0) }\end{array}$ & $\begin{array}{c}\text { Phospho- and sphingolipid } \\
\text { metabolism }\end{array}$ \\
\hline Humans & Plasma & $\begin{array}{c}\text { Photometric } \\
\text { assays, } \\
\text { immuno-assays }\end{array}$ & $\begin{array}{c}\text { Cholesterol (HDL } \text {, LDL }^{6} \text { ), } \\
\text { fructosamine, triglycerides, } \\
\text { free fatty acids, } \\
\text { dehydro-epiandrosterone-sulfate, } \\
\text { adrenocorticotropic hormone }\end{array}$ & $\begin{array}{c}\text { Lipid and carbohydrate } \\
\text { metabolism }\end{array}$ \\
\hline Humans & Plasma & not specified & $\begin{array}{c}\text { Cholesterol, triglycerides, } \\
\text { apolipoproteins B }\end{array}$ & [42] \\
\hline Humans & Urine & GC-MS & $\begin{array}{c}\text { N-methylnicotin-amide, } \\
\text { amino-malonic acid, azelaic } \\
\text { acid, hippuric acid }\end{array}$ & $\begin{array}{c}\text { Tryptophan-nicotinic acid } \\
\text { metabolism, lipid metabolism, } \\
\text { tyrosine-phenylalanine pathways }\end{array}$ \\
\hline
\end{tabular}

${ }^{1}$ GC-MS, gas chromatography-mass spectrometry. ${ }^{2}$ Hypothalamus-pituitary-adrenal. ${ }^{3}$ LC-MS/MS, liquid chromatography-tandem mass spectrometry. ${ }^{4}$ LC-MS, liquid chromatography-mass spectrometry. ${ }^{5}$ HDL, high-density lipoproteins. ${ }^{6}$ LDL, low-density lipoproteins.

In human studies, mainly plasma sNamples were used for the study of metabolites. Overall, many early anxiety metabolomics studies focused on lipids (lipidomics), as there is a known connection between lipids and neuronal signaling and disease [45].

Negative correlations between anxiety and high-density lipoprotein (HDL) levels were observed, while higher triglyceride levels were observed in patients with depression and comorbid anxiety compared to depressive patients without anxiety [46]. Furthermore, serum triglycerides, very-low-density lipoprotein (VLDL)-cholesterol and free-cholesterol were higher in patients with anxiety disorders as compared to healthy controls, whereas the opposite was observed for esterified cholesterol [47]. A study conducted in menopausal women observed no correlation between lipid profiles (total cholesterol, HDL, VLDL, low-density lipoproteins (LDL), triglycerides) and anxiety [48]. In young women, on the other hand, low lipid and lipoprotein levels (cholesterol, LDL, total cholesterol, ratio of total cholesterol to HDL) were inversely correlated with anxiety scores [49]. Huang et al. [50] observed differences in HDL cholesterol and the ratio of total cholesterol to HDL with regard to an anxious state in men. In healthy men, levels of total cholesterol and LDL cholesterol were higher in those who scored higher on an anxiety inventory [51]. Thus, several studies support the role of lipids in anxiety disorders, although differences with respect to gender and hormonal status likely exist.

Increasing evidence suggests a crucial role for membrane lipids and lipid oxidation in the pathogenesis of anxiety disorders. Membrane lipids play a pivotal role in the barrier and signaling function of membranes [52]. As dysfunctions in neuronal proteins and peptide activities are considered as a primary cause of anxiety disorders, brain lipids are essential for transmitter signaling. Lipids essential for membrane formation, i.e., n-3 polyunsaturated fatty acids, phospholipids, glycerolipids, and sphingolipids, are assumed to be involved in the pathogenesis of anxiety disorders, especially [53]. The lipid composition of neuronal membranes is highly dynamic and likely affects the assembly of signaling proteins and, thus, neuronal signaling and function [54].

Omega-3 fatty acids serve as precursors for the synthesis of eicosanoids, which might induce perturbations of the system of inflammatory mediators. Anxiety disorders have been linked to inflammation. Thus, the consumption of specific fatty acids or leukotriene receptor antagonists might also contribute to the maintenance of the anxiety symptoms [55].

Given the ubiquitous distribution of lipids at synapsis in the brain, membrane-forming lipids are believed to have high potential in the treatment of anxiety disorders [53]. As such, lipid-based therapies might offer new individualized treatment approaches, such as targeted dietary supplementation of n-3 polyunsaturated fatty acids [56]. Another mode of function might be pharmacological interference of lipids, i.e., glycerolipids, with lipid-regulating enzymes [57]. 
Observed changes in phospho- and sphingolipids related to anxiety symptoms pinpoint overactive ether lipid cleavage/turnover in the brain in the etiology of anxiety disorders, which likely relate to inflammatory processes [41].

The hypothesis of the association of anxiety with systemic inflammation corroborates a recent finding, showing an association of the inflammation marker C-reactive protein (CRP) [58], with increased risk of suicide in patients with anxiety disorders [59]. Thus, metabolites indicative of poor metabolic health might serve as distal biomarkers for anxiety. Indeed, metabolic health, as indicated by the analysis of 36 biomarkers (e.g., leptin, brain-derived neurotrophic factor, tryptophan), which have been shown to be related to anxiety disorders, revealed the highest occurrence of this mental disorder in individuals with poor metabolic health (the so-called "overweight" class). Therefore, metabolites indicative of poor metabolic health might serve as distal biomarkers for anxiety [60]. However, contrasting results on the association between inflammation and anxiety disorders have been reported. In elderly participants, for instance, a number of systemic inflammation markers (e.g., CRP, interleukins, serum amyloid A, tumor-necrosis factor alpha) were not associated with anxiety symptoms [61]. In another study with apparently healthy women, high-sensitivity CRP and fibrinogen contents were negatively associated with anxiety, whereas no association was observed in men [62]. Therefore, associations of anxiety and micro-inflammation markers also seem to differ with regard to gender and age, which might also contribute to the equivocal results regarding the association of lipid metabolism and inflammation with anxiety symptoms.

Studies also indicate a role of nitro-oxidative stress driving lipid oxidation and lowered lipid-antioxidant defenses in anxiety disorders. More specifically, increased superoxide dismutase, lipid hydroperoxides, nitric oxide metabolites (NOx), and uric acid were measured in individuals with general anxiety disorders than in those without anxiety disorders. Those changes were accompanied by a decrease in HDL and paraoxonase-1 [63]. It is suggested that the inflammation due to the overproduction of NOx is involved in the pathology of anxiety disorders [64]. However, while studies focusing on NOx levels in acute stress models observed associations between anxiety and NOx [65], a study analyzing salivary NOx in daily psychological stress in humans and anxiety observed only correlations between stress and anxiety, but not between salivary NOx and anxiety [64].

Several studies in animals and humans have demonstrated a potential link of anxiety disorders with oxidative stress and lipid peroxidation, as neurochemical causes of anxiety disorders. Lipid peroxidation was enhanced in children with anxiety disorders as compared to a control group, as indicated by increased serum levels of lipid hydroperoxide. Thus, lipid hydroperoxide has been speculated as a potential biomarker for anxiety disorders [3]. Oxidative stress as indicated by elevated levels of lipid hydroperoxide and lower paraoxonase activity (an HDL associated enzyme protecting lipids from peroxidation [66]) have been observed in individuals with generalized anxiety disorder (GAD) without any comorbid psychiatric disorder [67], further supporting the role of lipid peroxidation and oxidative stress in the etiopathogenesis of GAD. Thus, lipid hydroperoxide has been speculated as a potential biomarker for anxiety disorders $[3,67]$.

The association between anxiety and oxidative stress has often been related to nutritional effects. However, other factors might also serve as a source of oxidative stress, such as mobile phone electromagnetic field radiation, vibration and ringtone, which have been found to induce oxidative stress and anxiety-like behavior in rats [68].

As many studies highlight the association between stress and anxiety disorders, salivary cortisone was suggested not only as a stress biomarker but also as a marker of state anxiety [69]. Salivary alpha-amylase—a maker of sympathetic nervous system activity [70]—was observed to be higher in adults with a higher dental anxiety score, thus showing potential to serve as a biomarker of dental anxiety [71]. However, a study conducted in children with and without temporomandibular disorders observed higher anxiety symptoms in children with the disorder, but no difference in salivary alpha-amylase and also salivary cortisol [72]. However, elevated hair cortisol was found to predict later development of anxious behavior in response to a major life stressor in infant monkeys, thus showing 
some potential as a biomarker for stress-related mental problems [73]. In healthy volunteers exposed to a psychosocial stressor, the anxiety score was associated with salivary alpha-amylase, but not to salivary cortisol or chromogranin-A [74]. Therefore, further studies are needed to clarify whether cortisol, cortisone, and alpha-amylase show potential as biomarkers for anxiety disorders.

The neuropeptide pituitary adenylate cyclase-activating polypeptide (PACAP) is assumed to be involved in stress response and has been suggested as a biomarker for the severity of stress-related psychiatric disorders [75]. Serum PACAP analysis in male and female individuals diagnosed with GAD compared to healthy controls revealed no overall association between circulating PACAP and GAD, but an association in women [76], supporting prior work suggesting potential sex differences in PACAP effects, likely due to estrogen-dependent regulation of this pathway [75].

The neurotrophin fibroblast growth factor-2 (FGF2)-a protein involved in stress regulation and neurogeneration [77] - is also considered as an endogenous regulator of fear expression. Thus, FGF2 might also serve as a potential biomarker for anxiety disorders [78]; however, further research is required to elucidate the potential of FGF2 to identify vulnerable individuals and to establish preventative interventions.

Studies also aimed to integrate biopsychosocial aspects of stress, immune markers, and behavior in the development of anxiety symptoms. Chronic stress causes perturbations in the hypothalamuspituitary-adrenal (HPA)-axis, which might mediate the relationship between cardiovascular diseases and affective disorders [79]. One study investigated relations between stress, HPA-axis, and mother-child interaction patterns on the development of anxiety in children exposed to chronic trauma [80]. Trauma-exposed children exhibited more anxiety symptoms, which might be explained by three bio-behavioral paths: a mediated biological pathway through HPA-axis functioning (higher salivary cortisol in trauma-exposed mothers and also children), another biological pathway via the immune system (higher salivary immunoglobulin A (IgA) in trauma-exposed mothers and also children), and a third path with a behavioral link from diminished maternal supply to exposure to child anxiety. Moreover, anxiety in children exposed to continuous wartime trauma integrating endocrine and behavioral measures from mother and child was researched previously [81]. The study revealed that maternal physiology and behavior impacted child anxiety and three possible pathways were defined: augmentation of child anxiety through increased maternal salivary IgA, which led to enhanced child IgA; reduced social repertoire of the child due to reduced maternal oxytocin-and, in turn, reduced child oxytocin; and a direct impact of increased maternal anxiety on child anxiety.

Previous studies also attempted to reveal biological aspects of the higher prevalence of anxiety disorders in women. Differences in the hormonal status, i.e., with respect to the steroid pattern, have been speculated to be a reason behind. Higher levels of estrogens in women with anxiety disorders, when compared to women with depression, have been observed [82].

In one study, a specific analysis of the steroid metabolome in the blood of men with anxiety or depression compared to healthy controls was carried out. Conjugated steroid forms, i.e., sulfates, such as pregnenolone sulfate, differed between all three groups, and, thus, also provide an opportunity to serve as biomarkers to differentiate depressed from anxious individuals [83]. Among the previously considered steroids as being neuroactive, steroid sulfates, such as pregnenolone sulfate, are reported to act as negative gamma-aminobuytric acid (GABA) receptor modulators [84], which might explain the lower pregnenolone sulfate concentration in anxious and depressive men.

Besides plasma analysis, metabolomics analyses were also conducted on urine samples. Zheng et al. [44] used different metabolomics approaches to profile urine samples from healthy controls and patients with depression and anxiety disorders. Overall, four biomarkers- $N$-methylnicotinamide, aminomalonic acid, azelaic acid, and hippuric acid—were identified as being able to distinguish healthy from depressed/anxious individuals. Those biomarkers were mainly involved in three metabolic pathways (tryptophan-nicotinic acid metabolism, lipid metabolism, tyrosine-phenylalanine pathways) and five molecular and cellular functions (cell cycle, amino acid metabolism, molecular transport, cellular growth and proliferation, small molecule biochemistry). 
Further specific studies investigated comorbid anxiety disorders in specific disorders, such as autism, cancer, complex regional pain syndrome, or Cushing's syndrome. Only a few recent studies related to these specific diseases are summarized below.

Central and peripheral metabolites in patients with complex regional pain syndrome were analyzed for their association with psychological disorders, including anxiety [85]. Specific associations were observed, which might show pathological interactions between a painful body and increases in anxiety in this population. Strong positive correlations between valine/ $N$-acetylaspartylglutamate (val/tNAA) and anxiety in the right thalamus were observed. Lower NAA levels have been related to dysfunctional cell death related to neurons and glia cells. As lower NAA levels have been observed in patients with complex regional pain syndrome before, neuronal cell death may affect anxiety symptoms in this population $[86,87]$. In addition, peripheral $\mathrm{CO}_{2}$ was positively associated with anxiety, which might be explained by an increase in sensory pain levels due to increased partial $\mathrm{CO}_{2}$ pressure causing a synergistic boost of neuropsychiatric symptoms, such as anxiety [85].

An investigation in individuals with Cushing's syndrome evaluated the deleterious effects of excessive glucocorticoid exposure on neuronal changes related to anxiety [88]. Metabolomic analyses revealed a negative correlation of $\mathrm{N}$-Acetyl-aspartate (a marker of neuronal integrity and viability [89]) and creatinine (a marker for brain cell density in glial and neuronal cells, and energetic systems [90]) with anxiety, suggesting that long-term exposure to excessive glucocorticoid levels causes metabolic alterations in the prefrontal cortex associated with anxiety [88].

A study in patients with colorectal cancer undergoing three different stages of therapy, observed clinically relevant anxiety and/or depression levels in all patients [91]. Serum levels of fractaline (a chemokine involved in the progression of different types of tumors [92] and also in the inhibition of neurotransmission related to anxiety [93]) were positively correlated with anxiety scores. Therefore, fractaline might serve as a biomarker for the detection of anxiety disorders in cancer patients, and they might also assist in the development of personalized anxiolytic treatment strategies for cancer patients [91].

\section{Metabolomics in the Study of the Role of the Gut Microbiome in Anxiety Disorders}

The gut microbiome is suggested to play a pivotal role in the induction of anxiety-like behavior, through stress-induced dysbiosis [4]. The link of the gut microbiome and stress-related conditions has largely been investigated in studies with germ-free animals. A recent study in rats subjected to chronic unpredictable stress revealed that changes in the gut microbiome were accompanied by dysregulation of plasma metabolites related to metabolism of glycerophospholipids, glycerolipids, fatty acyls, and sterols [94]. The authors suggest that lactate produced from gut microbes might possibly promote anxiety-like behavior through the modulation of fatty acid metabolic pathways, resulting in low levels of plasma fatty acids. It was suggested that the future development of treatment strategies for anxiety disorders should consider targeting sphingolipid receptors.

In a further study with germ-free animals, these subjects had higher serotonin metabolite levels compared to conventionally raised controls. It was also suggested that the gut microbiome can affect the serotonergic neurotransmission in the central nervous system, through a humoral route, based on the finding of higher concentrations of the serotonin-precursor tryptophan in the plasma of germfree animals [95].

Furthermore, gender-differences in anxiety disorders have been observed in animal studies [4]. For instance, dietary supplementation with the n-3 polyunsaturated fatty acid docosahexaenoic acid (DHA) in male socially isolated mice reduced anxiety behaviors compared to controls, whereas no differences occurred in female mice [96]. In addition, a sex-specific interaction of the DHA-supplementation with the gut microbiome was observed, showing a significant effect on the microbiome in male but not in female mice.

Besides animal studies, human studies with respect to the role of the gut microbiome were also conducted, which mainly relied on correlative analysis. In this regard, Stevens et al. [97] investigated fecal 
microbiota in humans with anxiety or depressive disorders as compared to control reference subjects. Gut dysbiosis in anxious and depressed individuals and over-representation of lipopolysaccharide (LPS) biosynthesis genes in the gut microbiome were reflected in changes in metabolic pathways of mood neurotransmitters as well as deleterious metabolism of intestinal protective mucin and elevation of plasma LPS, and epithelium integrity molecules. These results support the notion that LPS might compromise the integrity of the gut barrier, causing systemic manifestations, including the brain [98].

The microbiota-gut-brain axis is also assumed to play a central role in the etiology of depression, showing that disturbances in the gut microbiome disturb metabolic homeostasis [30]. Several studies provide support that dysregulation of the enteric microbiome does not only produce detrimental metabolites but also causes increased bacterial translocation across the intestinal tract. These processes are assumed to be involved in the pathophysiology of anxiety and depressive disorders through proinflammatory cytokines and neuroinflammation, the HPA-axis, and vagal nerve activation, as reviewed recently [94]. Overall, based on these studies, future studies should elucidate the role of the gut as a novel target for the treatment of anxiety disorders.

\section{Metabolomics in the Study of the Role of Nutrition in Anxiety Disorders}

Several animal studies were conducted to evaluate the impact of different diets on anxiety. Some studies investigated the effect of maternal diet on the offspring. For instance, one study investigated the effect of maternal consumption of conjugated linoleic acid during gestation and lactation on cerebral lipid peroxidation and anxiety behavior in rats [99]. Higher levels of the antioxidant glutathione together with a lower concentration of the lipid peroxidation marker malondialdehyde were observed in brain tissues in the offspring of rats receiving conjugated linoleic acid. Maternal intake of conjugated linoleic acid also caused an anxiolytic effect in the offspring. Therefore, results imply that an adequate supply of essential fatty acids during pregnancy plays an important role in facilitating the development of the nervous system and protecting the offspring from neuronal changes, such as those leading to anxiety.

In a further study, the offspring of rats received a diet consisting of high contents of simple carbohydrates, saturated or trans-fats, sodium, and low protein and fiber contents (a so-called "cafeteria diet") during lactation and/or post-lactation compared to rats receiving a control diet [100]. The effects of this cafeteria diet on physiological parameters and anxiety were investigated. The highest triglyceride levels were found in the offspring of rats receiving post-lactation cafeteria diet or total cafeteria diet. The offspring also presented higher levels of anxiety compared to the control groups and groups with only a lactational cafeteria diet. Thus, the study provides some evidence that the ingestion of a cafeteria diet after lactation might trigger metabolic (increase in serum triglycerides and oxidative stress) and behavioral alterations (anxiogenic effects) in rats.

A broad range of studies investigated nutritional biomarkers and anxiety during pregnancy and postpartum in humans, as recently systematically reviewed by Trujillo et al. [101]. Most relevant studies are briefly described in the following.

One study related to anxiety disorders during pregnancy to nutritional biomarkers. Associations between polyunsaturated fatty acids and anxiety disorders in early pregnancy were observed, showing an inverse relation of serum DHA levels and anxiety disorders in the first trimester [102]. Furthermore, associations between cholesterol and anxiety in the postpartum period were investigated, as total lipids decrease considerably after delivery as compared to pregnancy [103]. Overall, only moderate negative associations between total cholesterol and HDL cholesterol and anxiety symptoms were observed in the postpartum period [104].

Next to the effects of fatty acids, a possible association between amino acids and anxiety was also studied [105], showing an inverse relationship of the ratio of plasma tryptophan and the sum of the levels of valine, leucine, isoleucine, and phenylalanine with anxiety. Moreover, changes in plasma phenylalanine were correlated with changes in anxiety scores from the 3rd to 6th day before delivery 
to the 1st and 3rd postnatal day; however, these associations should be interpreted with caution, as only low correlations $(\mathrm{r}=0.16, p=0.04)$ were observed [106].

The role of micronutrients has hardly been investigated so far, showing no association of vitamin D with anxiety in pregnancy [107] and also no correlation between zinc levels and anxiety during pregnancy and in the postpartum period [108].

Further studies investigated possible associations between obesity/metabolic syndrome and anxiety disorders using animal models. For instance, in rats fed a high-saturated fat or a high-fat and high-fructose diet, behavioral alterations toward anxiety-like behavior were observed [109]. These behavioral alterations correlated with dyslipidemia (increased serum triglycerides and cholesterol), lipid peroxidation, and metabolic parameters. Long-term feeding of high-fat diets has also shown to increase malondialdehyde concentrations and to decrease glutathione levels in the serum of rats, which went along with increases in anxiety-like behavior [110].

In humans, a cross-sectional study investigated associations of anxiety and metabolic syndrome components in metabolic syndrome patients. Waist, body mass index, and degree of obesity, and the hypertension component could be linked to systolic blood pressure, pulse pressure, total cholesterol, and trait anxiety, but not to state anxiety. Thus, cholesterol metabolism, blood pressure, and high trait-anxiety likely interact in the pathophysiology of hypertension in metabolic syndrome [76].

Studies conducted in animals and humans reveal an inverse relationship of the dietary total antioxidant capacity with oxidative stress biomarkers as well anxiety [111]. Therefore, lipid peroxidation does not only seem to play a role during pregnancy/early life, but also in adults.

Overall, research indicates that nutrition-mainly associated with lipid peroxidation, inflammation, and metabolic alterations-plays a role in translating diet-induced metabolic alterations into anxiety disorders. Therefore, fatty acids, such as n-3 polyunsaturated fatty acids, or the provision of antioxidants, are also considered as new treatment options $[53,110,111]$.

\section{Metabolomics in the Study of Anxiolytic Effects}

Metabolomics was also applied in the field of drug discovery, including natural product research.

Several studies used metabolomics analyses to characterize the composition of anxiolytic drugs/natural products [112], which will not be described in more detail as it does not fall within the scope of this review. However, in some studies, changes in brain or plasma metabolites due to drug administration were also assessed, as summarized in Table 2. These studies highlight the role of the effects of anxiolytic drugs on neurotransmitter metabolism, but also on antioxidant mechanisms. Several studies pinpoint the involvement of changes in serotonergic activity in the anxiolytic effect of several drugs, showing increasing serotonin contents in rodent brains $[113,114]$. In addition, the role of dopamine in anxiety has been reported before, revealing increasing concentrations in the prefrontal cortex during stressful and anxiogenic situations [113], and a decrease after the administration of anxiolytic drugs, such as afobazole [114]. However, for other drugs, such as diazepam, no effect on the dopamine content was observed, despite their anxiolytic activity [113]. Next to serotonin and dopamine, the glutamate-glutamine cycle in the brain plays an essential role in mental disorders [115], as glutamate represents the primary and most abundant excitatory neurotransmitter in the central nervous system. The functionality of the glutamate-glutamine cycle is essential for glutaminergic neurotransmission [116]. Furthermore, glutamine is not only essential as a precursor for the neurotransmitter glutamate but also for the neurotransmitter GABA [115] and the antioxidant glutathione [117]. The dysfunction of the glutamate-glutamine cycle is suggested to be involved in different forms of anxieties [40]. Therefore, several anxiolytic drugs might pose their anxiolytic effects via their impact on this cycle, as summarized in Table 2.

In the following, only a few recent studies using metabolomic approaches in the study of anxiolytic effects are reported in more detail.

The ethanol extract of Passiflora edulis Sims F. flavicarpa was tested in comparison to a positive drug control (diazepam) in a randomized trial using an anxiety model in rats. Administration 
of $P$. edulis extract enhanced GABA concentrations in the brain and exhibited an anxiolytic-like effect. Thus, it is assumed that P. edulis extracts might function as positive allosteric modulators of GABA. Using metabolomics approaches, secondary metabolites were investigated and correlated with measured activities. However, no correlation of the different metabolites was observed, suggesting that the anxiolytic effect is not attributable to a single metabolite, but rather to an additive or synergistic effect of several entities [118].

In line with the research indicating a role of oxidative stress in the etiology of anxiety disorders, a meta-analysis by Aponso et al. [119] reported anxiolytic effects of inhaled essential oils as well reduced oxidative stress. Moreover, extracts of Hypericum Scabrum-a phyto drug with antioxidant properties-were shown to be able to reverse diet-induced alterations related to oxidative stress [110]. More specifically, detrimental effects of high levels of saturated fats on oxidative status and anxious behavior were observed in rats. A long-term high-fat diet enhanced serum malondialdehyde levels, decreased glutathione levels, and enhanced anxiety. The extract of $\mathrm{H}$. scabrum inversed these diet-induced alterations and decreased anxiolytic effects. Therefore, it is expected that phytomedical, natural therapeutic agents with antioxidant properties might offer preventative and/or curative measures in anxiety disorders.

The linkage of psychological stress and production of free radicals with anxiety disorders was also used to investigate oxidative metabolites as biomarkers for monitoring the response to treatment with anxiolytics in a randomized placebo-controlled study [120]. Biopyrrins, the oxidative metabolites of bilirubin, were investigated in urinary samples of mice receiving the anxiolytic alprazolam subjected to acute stress. In addition, corticosterone levels in serum were analyzed. An increase in biopyrrins in stressed mice and a decrease after the anxiolytic treatment, as well as a correlation between urinary biopyrrins and serum corticosterone levels, were observed, thus showing some potential for urinary biopyrrins to serve as biomarkers for the assessment of the response to anxiolytics.

Indicators of stress and lipid peroxidation were also investigated in the brain of psychologicallystressed mice receiving anxiolytic and anxiogenic drugs [121]. The content of thiobarbituric acid reactive substances-an index of lipid peroxidation activity-was enhanced in the brain, but not in the liver or serum after stress exposure. The oxidative brain damage in the brain lipids went along with the enhanced production of nitric oxidase through the mediation of non-selective nitric oxidase synthase. The stress-induced detrimental effects were suppressed by anxiolytic drugs. Thus, drugs with benzodiazepine or a serotonin receptor agonist profile might pose anxiolytic effects due to their protective effects on stress-induced oxidative brain damage.

Further studies point at the pivotal role of the antioxidant effects of anxiolytics. For instance, the anxiolytic-like effect and the possible neuronal mechanism of action of the chemical isopentyl ferulate (IF) were investigated in a randomized trial in mice with a negative control group. Overall, the calming effect of IF went along with a decrease in hippocampal nitrite and lipid peroxidation levels and an increase in glutathione and antioxidative enzymes (glutathione peroxidase, superoxide dismutase, catalase). Further investigations regarding possible involvement of the GABAergic system in the anxiolytic effect of IF yielded some evidence that IF might show neuroprotective effects through the GABAergic transmission pathway [122].

Anxiolytic effects of satins-drugs that are used to lower LDL levels-were also discussed in a recent review article [123]. The mechanisms behind it are assumed due to a modulation of the $\mathrm{N}$-methyl-D-aspartate (NMDA) receptors in the brain, which show a close correlation with anxiety-like behavior. Statins can disable these NMDA receptors due to their role in the disruption of membrane/lipid rafts, finally disabling the NMDA receptor-mediated anxiety. 
Table 2. Overview of metabolomic studies in the study of anxiolytic effects.

\begin{tabular}{|c|c|c|c|c|c|c|}
\hline Subject & $\begin{array}{c}\text { Sampling } \\
\text { Material }\end{array}$ & $\begin{array}{l}\text { Analytical } \\
\text { Platform }\end{array}$ & Anxiolytic Drug & Metabolites Identified & $\begin{array}{c}\text { Pathways } \\
\text { Involved/Functions }\end{array}$ & Reference \\
\hline Mice & Brain & $\mathrm{NMR}^{1}$ & $\begin{array}{l}\text { Specific herbal } \\
\text { formula (Fu Fang } \\
\text { Jin oral liquid) }\end{array}$ & $\begin{array}{c}\text { ATP, fumarate, malate, lactate, } \\
\text { glycine, GABA }{ }^{2}, \\
N \text {-acetyl-aspartyl-glutamate }\end{array}$ & $\begin{array}{c}\text { Energy metabolism, } \\
\text { choline metabolism, } \\
\text { neuro-transmitter } \\
\text { metabolism }\end{array}$ & [124] \\
\hline Mice & Brain & HPLC $^{3}$ & $\begin{array}{l}\text { (Z)-3-hexenol, } \\
\text { Diazepam }\end{array}$ & $\begin{array}{c}\text { Serotonin } \\
\left(\text { 5-hydroxy-tryptamine; } 5-\mathrm{HT}^{4}{ }^{4}\right) \\
\text { 5-hydroxyindoleacetic acid }\end{array}$ & $\begin{array}{l}\text { Neuro-transmitter } \\
\text { metabolism }\end{array}$ & [113] \\
\hline Rats & Brain & not specified & $\begin{array}{l}\text { Afobazole, } \\
\text { Ladasten }\end{array}$ & $\begin{array}{l}\text { 3,4-dihydroxy-phenylacetic } \\
\text { acid, homovanillic acid, 5-HT, } \\
5 \text { oxytryptophan, } \\
\text { 5-hydroxyindoleacetic acid, } \\
\text { L-3,4-dihydroxy-phenylalanine }\end{array}$ & $\begin{array}{l}\text { Neuro-transmitter } \\
\text { metabolism }\end{array}$ & [114] \\
\hline Rats & Brain & HPLC-ED ${ }^{5}$ & Imipramine & $\begin{array}{c}5 \text { oxytryptophan, } \\
\text { homovanillic acid, } \\
\text { dihydroxyphenylacetic acid }\end{array}$ & $\begin{array}{l}\text { Neuro-transmitter } \\
\text { metabolism }\end{array}$ & [125] \\
\hline Rats & Brain & UPLC-MS ${ }^{6}$ & $\begin{array}{l}\text { Passiflora edulis } \\
\text { Sims F. flavicarpa, } \\
\text { diazepam }\end{array}$ & GABA & $\begin{array}{l}\text { Neuro-transmitter } \\
\text { metabolism }\end{array}$ & [118] \\
\hline Mice & $\begin{array}{l}\text { Urine, } \\
\text { serum }\end{array}$ & Immuno-assays & Alprazolam & Biopyrrins, corticosterone & Oxidative stress & [120] \\
\hline Mice & Brain & $\begin{array}{l}\text { Antioxidant } \\
\text { assays }\end{array}$ & Isopentyl ferulate & $\begin{array}{c}\text { Nitrite and lipid peroxidation } \\
\text { markers, glutathione, } \\
\text { glutathione peroxidase, } \\
\text { superoxide dismutase, } \\
\text { catalase }\end{array}$ & $\begin{array}{l}\text { Oxidative stress, } \\
\text { neuro-transmitter } \\
\text { metabolism }\end{array}$ & [122] \\
\hline
\end{tabular}

\footnotetext{
${ }^{1} \mathrm{NMR}$, nuclear magnetic resonance spectroscopy. ${ }^{2} \mathrm{GABA}$, gamma-aminobuytric acid. ${ }^{3} \mathrm{HPLC}$, high-performance liquid chromatography. ${ }^{4}$ 5-HT, serotonin, 5-hydroxytryptamine. ${ }^{5}$ HPLC-ED, high-performance liquid chromatographyelectrochemical detection. ${ }^{6}$ UPLC-MS, ultra-performance liquid chromatography-mass spectrometry.
}

In a case study in a patient with a treatment-refractory substance use disorder and comorbid anxiety and depressive symptoms, repeated transcranial magnetic stimulation was successful in reducing anxiety symptoms [126]. It was speculated that enhanced glutamate transmission in the corticostriatal pathways occurred due to the stimulation of the dorsolateral prefrontal cortex. This might, in turn, modulate the GABA/glutamate balance within the basal ganglia, which, in turn, promotes dopamine release in the mesocortical pathways, finally reducing psychiatric symptoms.

Lifestyle changes, such as nutritional changes or exercise, have been proposed as possible complementary modalities to prevent and cure disorders, and the combination of both approaches, i.e., dietary supplementation with polyunsaturated fatty acids in combination with physical exercise, showed synergistic effects on brain function and behavior $[127,128]$. A study in mice investigated the effect of voluntary running on anxiety-like behavior and the lipid metabolome in the brain and blood corticosterone levels. Compared to sedentary mice, the running group displayed lower anxiety-like behavior, which went along with differences in blood corticosterone and a region-specific cortical decrease in the palmitate (C16:0) and a concomitant increase in arachidonic acid and DHA. Therefore, it is assumed that the anxiolytic effects of physical exercise derive from exercise-induced activation of cortical signaling cascades involving or dependent on bioactive lipids [129]. In humans, physical exercise (strength and endurance training) reduced anxiety, which went along with a reduction in CRP, an indicator of cardiac veins inflammation [130], with the latter being stronger affected by strength than endurance training [131]. Tai Chi Chuan is often viewed by Chinese people as physical exercise to improve mind-body health, therefore, making it an interesting research target in the field of cardiovascular health and anxiety symptoms. Thus, a randomized-controlled trial was conducted to evaluate the effect of a Tai Chi Chuan exercise program on anxiety status and blood lipid profile in individuals with hypertension as compared to healthy subjects [132]. As an increase in HDL and a decrease in total cholesterol, LDL, and triglycerides went along with decreases in trait and state anxiety, it was suggested that Tai Chi might be used as an alternative treatment in patients with anxiety disorders. 


\section{Conclusions}

The aforementioned studies on the use of metabolomics in anxiety disorders are promising for diagnosis, gaining insight into the etiology of the disorders and the development of treatment strategies. Overall, metabolites related to oxidative stress, inflammatory processes, lipid and energy metabolism, glutamine metabolism, and neurotransmission seem to pose the potential to serve as biomarkers for anxiety disorders; however, to date, the application in clinical practice is not feasible due to several limitations. The main limitation is that, so far, no references for normal ranges of metabolites exist [30]. Furthermore, variables, such as gender, diet, or lifestyle, affect the metabolic profile and also medical comorbidities and the use of medications or drugs need to be considered and, thus require further research $[133,134]$. Furthermore, many findings of this systematic review are based on animal studies. Those studies on human anxiety were also prevalent beneath other disorders. It must be taken into account that the group of anxiety disorders is from the clinical and etiological point of view very different. Thus, a more specific approach, according to the different categories of anxiety disorders, might be more efficient. There is also a lack of research on whether metabolomic biomarkers can predict or moderate treatment response to anxiolytic medication and psychotherapy. However, in major depressive disorders, for instance, studies indicate predictive potential of the pretreatment metabolomics profile of the response to antidepressant medication [135], and also one pilot psychotherapy study revealed that several plasma metabolites might serve as moderators of the outcome of psychotherapy [136]. Future studies should also explore metabolomics changes in anxiety due to psychotherapy treatment, which might also help to understand better the mechanistic underpinnings of the effect of psychotherapy on symptom change and whether these changes are associated with metabolomics alterations. Therefore, more research is needed to reveal whether metabolomics can provide biomarkers to improve treatment selection and personalized treatment for patients with anxiety disorders.

Author Contributions: Conceptualization, E.H.; Methodology, E.H., C.P., T.P.; Investigation, E.H.; Writing—original draft preparation, E.H.; Writing—review and editing, C.P., T.P.; Supervision, C.P., T.P. All authors have read and agreed to the published version of the manuscript.

Funding: This research received Open Access Funding by the University for Continuing Education Krems.

Conflicts of Interest: The authors declare no conflict of interest.

\section{Abbreviations}

$\begin{array}{ll}\text { CER } & \text { Ceramides } \\ \text { CRP } & \text { C-reactive protein } \\ \text { DHA } & \text { Docosahexaenoic acid } \\ \text { DOPA } & \text { Dopamine } \\ \text { FGF2 } & \text { Fibroblast growth factor-2 } \\ \text { GABA } & \text { Gamma-aminobuytric acid } \\ \text { GAD } & \text { Generalized Anxiety Disorder } \\ \text { GC-MS } & \text { Gas chromatography-mass spectrometry } \\ \text { HDL } & \text { High-density lipoprotein } \\ \text { HPA } & \text { Hypothalamus-pituitary-adrenal } \\ \text { HPLC } & \text { High-performance liquid chromatography } \\ \text { HPLC-ED } & \text { High-performance liquid chromatography-electrochemical detection } \\ \text { 5-HT } & \text { Serotonin } \\ \text { IgA } & \text { Immunoglobulin A } \\ \text { LC-MS } & \text { Liquid chromatography-mass spectrometry } \\ \text { LC-MS/MS } & \text { Liquid chromatography-tandem mass spectrometry } \\ \text { LDL } & \text { Low-density lipoprotein } \\ \text { LPS } & \text { Lipopolysaccharides } \\ \text { NAA } & \text { N-acetylaspartylglutamate } \\ \text { NMR } & \text { Nuclear magnetic resonance spectroscopy }\end{array}$




$\begin{array}{ll}\text { NOx } & \text { Nitric oxide metabolites } \\ \text { PACAP } & \text { Pituitary adenylate cyclase-activating polypeptide } \\ \text { PC } & \text { Phosphatidylcholines } \\ \text { UPLC-MS } & \text { Ultra-performance liquid chromatography-mass spectrometry } \\ \text { VLDL } & \text { Very low-density lipoprotein }\end{array}$

\section{References}

1. WHO. Depression and Other Common Mental Disorders. Global Health Estimates. 2017; WHO: Geneva, Switzerland, 2017.

2. Shadli, S.M.; McIntosh, J.; McNaughton, N. Anxiety process "theta" biomarker in the stop signal task eliminated by a preceding relaxation test. Behav. Neurosci. 2020, in press. [CrossRef] [PubMed]

3. Ceylan, M.F.; Guney, E.; Alisik, M.; Ergin, M.; Dinc, G.S.; Goker, Z.; Eker, S.; Kizilgun, M.; Erel, O. Lipid peroxidation markers in children with anxiety disorders and their diagnostic implications. Redox Rep. 2014, 19, 92-96. [CrossRef] [PubMed]

4. Jalnapurkar, I.; Allen, M.; Pigott, T. Sex differences in anxiety disorders: A review. Pda J. Pharmacol. Sci. Technol. 2018, 4, 1-9. [CrossRef]

5. Byrne, G.J. What happens to anxiety disorders in later life? Rev. Bras. Psiquiatr. 2002, 24, 74-80. [CrossRef]

6. American Psychiatric Association. Diagnostic and Statistical Manual of Mental Disorders, 5th ed.; American Psychiatric Association: Washington, DC, USA, 2013; ISBN 978-0-89042-555-8.

7. Stein, D.J.; Scott, K.M.; de Jonge, P.; Kessler, R.C. Epidemiology of anxiety disorders: From surveys to nosology and back. Dialogues Clin. Neurosci. 2017, 19, 127-136. [PubMed]

8. Kendler, K.S. The structure of psychiatric science. AJP 2014, 171, 931-938. [CrossRef] [PubMed]

9. Loerinc, A.G.; Meuret, A.E.; Twohig, M.P.; Rosenfield, D.; Bluett, E.J.; Craske, M.G. Response rates for CBT for anxiety disorders: Need for standardized criteria. Clin. Psychol. Rev. 2015, 42, 72-82. [CrossRef] [PubMed]

10. Baldwin, D.; Woods, R.; Lawson, R.; Taylor, D. Efficacy of drug treatments for generalised anxiety disorder: Systematic review and meta-analysis. BMJ 2011, 342, d1199. [CrossRef]

11. Olatunji, B.O.; Cisler, J.M.; Deacon, B.J. Efficacy of cognitive behavioral therapy for anxiety disorders: A review of meta-analytic findings. Psychiatr. Clin. N. Am. 2010, 33, 557-577. [CrossRef]

12. Vøllestad, J.; Nielsen, M.B.; Nielsen, G.H. Mindfulness- and acceptance-based interventions for anxiety disorders: A systematic review and meta-analysis: Mindfulness- and acceptance-based interventions for anxiety disorders. Br. J. Clin. Psychol. 2012, 51, 239-260. [CrossRef]

13. Bandelow, B.; Reitt, M.; Röver, C.; Michaelis, S.; Görlich, Y.; Wedekind, D. Efficacy of treatments for anxiety disorders: A meta-analysis. Int. Clin. Psychopharmacol. 2015, 30, 183-192. [CrossRef] [PubMed]

14. Kapur, S.; Phillips, A.G.; Insel, T.R. Why has it taken so long for biological psychiatry to develop clinical tests and what to do about it? Mol. Psychiatry 2012, 17, 1174-1179. [CrossRef] [PubMed]

15. Roest, A.M.; de Jonge, P.; Williams, C.D.; de Vries, Y.A.; Schoevers, R.A.; Turner, E.H. Reporting bias in clinical trials investigating the efficacy of second-generation antidepressants in the treatment of anxiety disorders: A report of 2 meta-analyses. Jama Psychiatry 2015, 72, 500. [CrossRef] [PubMed]

16. Insel, T.; Cuthbert, B.; Garvey, M.; Heinssen, R.; Pine, D.S.; Quinn, K.; Sanislow, C.; Wang, P. Research Domain Criteria (RDoC): Toward a new classification framework for research on mental disorders. AJP 2010, 167, 748-751. [CrossRef] [PubMed]

17. Schneider, R.L.; Arch, J.J.; Wolitzky-Taylor, K.B. The state of personalized treatment for anxiety disorders: A systematic review of treatment moderators. Clin. Psychol. Rev. 2015, 38, 39-54. [CrossRef]

18. Biomarkers Definitions Working Group. Biomarkers and surrogate endpoints: Preferred definitions and conceptual framework. Clin. Pharmacol. Ther. 2001, 69, 89-95. [CrossRef]

19. Sethi, S.; Brietzke, E. Omics-Based biomarkers: Application of metabolomics in neuropsychiatric disorders. IJNPPY 2016, 19, pyv096. [CrossRef]

20. Guest, P.C.; Guest, F.L.; Martins-de Souza, D. Making sense of blood-based proteomics and metabolomics in psychiatric research. IJNPPY 2016, 19, pyv138. [CrossRef]

21. Dettmer, K.; Aronov, P.A.; Hammock, B.D. Mass spectrometry-based metabolomics. Mass Spectrom. Rev. 2007, 26, 51-78. [CrossRef] 
22. Kaddurah-Daouk, R.; Krishnan, K.R.R. Metabolomics: A global biochemical approach to the study of central nervous system diseases. Neuropsychopharmacology 2009, 34, 173-186. [CrossRef]

23. Pasikanti, K.K.; Ho, P.C.; Chan, E.C.Y. Gas chromatography/mass spectrometry in metabolic profiling of biological fluids. J. Chromatogr. B 2008, 871, 202-211. [CrossRef] [PubMed]

24. Tweeddale, H.; Notley-McRobb, L.; Ferenci, T. Effect of slow growth on metabolism of Escherichia coli, as revealed by global metabolite pool ("metabolome") analysis. J. Bacteriol. 1998, 180, 5109-5116. [CrossRef] [PubMed]

25. Fernie, A.R.; Trethewey, R.N.; Krotzky, A.J.; Willmitzer, L. Metabolite profiling: From diagnostics to systems biology. Nat. Rev. Mol. Cell Biol. 2004, 5, 763-769. [CrossRef]

26. Renoir, T.; Hasebe, K.; Gray, L. Mind and body: How the health of the body impacts on neuropsychiatry. Front. Pharm. 2013, 4. [CrossRef]

27. Abu-Asab, M.S.; Chaouchi, M.; Alesci, S.; Galli, S.; Laassri, M.; Cheema, A.K.; Atouf, F.; VanMeter, J.; Amri, H. Biomarkers in the age of omics: Time for a systems biology approach. Omics J. Integr. Biol. 2011, 15, 105-112. [CrossRef] [PubMed]

28. Nordström, A.; Lewensohn, R. Metabolomics: Moving to the clinic. J. Neuroimmune Pharm. 2010, 5, 4-17. [CrossRef] [PubMed]

29. Zhao, L.; Zhang, Z.; Zhou, M.; Gou, X.; Zeng, Y.; Song, J.; Ma, W.; Xu, Y. A urinary metabolomics (GC-MS) strategy to evaluate the antidepressant-like effect of chlorogenic acid in adrenocorticotropic hormone-treated rats. Rsc Adv. 2018, 8, 9141-9151. [CrossRef]

30. Wood, P.L. Mass spectrometry strategies for clinical metabolomics and lipidomics in psychiatry, neurology, and neuro-oncology. Neuropsychopharmacology 2014, 39, 24-33. [CrossRef]

31. Puchades-Carrasco, L.; Pineda-Lucena, A. Metabolomics applications in precision medicine: An oncological perspective. Curr. Top. Med. Chem. 2017, 17, 2740-2751. [CrossRef]

32. Ozomaro, U.; Wahlestedt, C.; Nemeroff, C.B. Personalized medicine in psychiatry: Problems and promises. Bmc Med. 2013, 11, 132. [CrossRef]

33. Deng, F.-L.; Pan, J.-X.; Zheng, P.; Xia, J.-J.; Yin, B.-M.; Liang, W.-W.; Li, Y.-F.; Wu, J.; Xu, F.; Wu, Q.-Y.; et al. Metabonomics reveals peripheral and central short-chain fatty acid and amino acid dysfunction in a naturally occurring depressive model of macaques. NDT 2019, 15, 1077-1088. [CrossRef]

34. Humer, E.; Probst, T.; Pieh, C. Metabolomics in psychiatric disorders: What we learn from animal models. Metabolites 2020, 10, 72. [CrossRef] [PubMed]

35. Nedic Erjavec, G.; Konjevod, M.; Nikolac Perkovic, M.; Svob Strac, D.; Tudor, L.; Barbas, C.; Grune, T.; Zarkovic, N.; Pivac, N. Short overview on metabolomic approach and redox changes in psychiatric disorders. Redox Biol. 2018, 14, 178-186. [CrossRef]

36. Donati, R.J.; Rasenick, M.M. G protein signaling and the molecular basis of antidepressant action. Life Sci. 2003, 73, 1-17. [CrossRef]

37. Zhang, Y.; Filiou, M.D.; Reckow, S.; Gormanns, P.; Maccarrone, G.; Kessler, M.S.; Frank, E.; Hambsch, B.; Holsboer, F.; Landgraf, R.; et al. Proteomic and metabolomic profiling of a trait anxiety mouse model implicate affected pathways. Mol. Cell Proteom. 2011, 10, M111.008110. [CrossRef] [PubMed]

38. Filiou, M.D.; Zhang, Y.; Teplytska, L.; Reckow, S.; Gormanns, P.; Maccarrone, G.; Frank, E.; Kessler, M.S.; Hambsch, B.; Nussbaumer, M.; et al. Proteomics and metabolomics analysis of a trait anxiety mouse model reveals divergent mitochondrial pathways. Biol. Psychiatry 2011, 70, 1074-1082. [CrossRef]

39. Filiou, M.D.; Asara, J.M.; Nussbaumer, M.; Teplytska, L.; Landgraf, R.; Turck, C.W. Behavioral extremes of trait anxiety in mice are characterized by distinct metabolic profiles. J. Psychiatr. Res. 2014, 58, 115-122. [CrossRef]

40. Puurunen, J.; Tiira, K.; Vapalahti, K.; Lehtonen, M.; Hanhineva, K.; Lohi, H. Fearful dogs have increased plasma glutamine and $\gamma$-glutamyl glutamine. Sci. Rep. 2018, 8, 1-12. [CrossRef]

41. Demirkan, A.; Isaacs, A.; Ugocsai, P.; Liebisch, G.; Struchalin, M.; Rudan, I.; Wilson, J.F.; Pramstaller, P.P.; Gyllensten, U.; Campbell, H.; et al. Plasma phosphatidylcholine and sphingomyelin concentrations are associated with depression and anxiety symptoms in a Dutch family-based lipidomics study. J. Psychiatr. Res. 2013, 47, 357-362. [CrossRef]

42. Lieberman, H.R.; Kellogg, M.D.; Kramer, F.M.; Bathalon, G.P.; Lesher, L.L. Lipid and other plasma markers are associated with anxiety, depression, and fatigue. Health Psychol. 2012, 31, 210-216. [CrossRef] 
43. Pistorio, E.; Luca, M.; Luca, A.; Messina, V.; Calandra, C. Autonomic nervous system and lipid metabolism: Findings in anxious-depressive spectrum and eating disorders. Lipids Health Dis. 2011, 10, 192. [CrossRef] [PubMed]

44. Chen, J.; Bai, S.-J.; Li, W.; Zhou, C.; Zheng, P.; Fang, L.; Wang, H.; Liu, Y.; Xie, P. Urinary biomarker panel for diagnosing patients with depression and anxiety disorders. Transl. Psychiatry 2018, 8, 1-10. [CrossRef]

45. Tracey, T.J.; Steyn, F.J.; Wolvetang, E.J.; Ngo, S.T. Neuronal lipid metabolism: Multiple pathways driving functional outcomes in health and disease. Front. Mol. Neurosci. 2018, 11, 10. [CrossRef]

46. Wang, J.; Jiang, C.; Chen, L.; Wu, S.; Lin, J.; Gao, L.; Xie, B.; Zheng, D.; Yang, R.; Li, S.; et al. A cross-sectional study to investigate the correlation between depression comorbid with anxiety and serum lipid levels. Compr. Psychiatry 2016, 69, 163-168. [CrossRef] [PubMed]

47. Mishra, T.K.; Shankar, R.; Sharma, I.; Srivastava, P.K. Serum lipids in anxiety neurosis. Indian J. Psychiatry 1984, 26, 237-241. [PubMed]

48. Chen, C.-C.; Huang, T.-L. Association of serum lipid profiles with depressive and anxiety disorders in menopausal women. Chang. Gung Med. J. 2006, 29, 325. [PubMed]

49. Suarez, E.C. Relations of trait depression and anxiety to low lipid and lipoprotein concentrations in healthy young adult women. Psychosom. Med. 1999, 61, 273-279. [CrossRef]

50. Huang, T.-L.; Wu, S.-C.; Chiang, Y.-S.; Chen, J.-F. Correlation between serum lipid, lipoprotein concentrations and anxious state, depressive state or major depressive disorder. Psychiatry Res. 2003, 118, 147-153. [CrossRef]

51. Pooradl, M.; Alipour, A.; Dehkordi, M.A.; Farrokhi, M. Associations between Self-Reported Anxiety and Serum Lipid, Lipoprotein Concentrations and Platelets in Healthy Men. Neurology Asia. 2013, 18, 87-93.

52. Casares, D.; Escribá, P.V.; Rosselló, C.A. Membrane lipid composition: Effect on membrane and organelle structure, function and compartmentalization and therapeutic avenues. Int. J. Mol. Sci. 2019, 20, 2167. [CrossRef]

53. Müller, C.P.; Reichel, M.; Mühle, C.; Rhein, C.; Gulbins, E.; Kornhuber, J. Brain membrane lipids in major depression and anxiety disorders. Biochim. Biophys. Acta (Bba)—Mol. Cell Biol. Lipids 2015, 1851, 1052-1065. [CrossRef]

54. Postila, P.A.; Róg, T. A perspective: Active role of lipids in neurotransmitter dynamics. Mol. Neurobiol. 2020, 57, 910-925. [CrossRef] [PubMed]

55. McCarter, G.C.; Blanchard, L.B. Similar adverse events from two disparate agents implicate lipid inflammatory mediators for a role in anxiety states. Oxf. Med. Case Rep. 2017, 2017, omx060. [CrossRef] [PubMed]

56. Su, K.-P.; Tseng, P.-T.; Lin, P.-Y.; Okubo, R.; Chen, T.-Y.; Chen, Y.-W.; Matsuoka, Y.J. Association of use of omega-3 polyunsaturated fatty acids with changes in severity of anxiety symptoms: A systematic review and meta-analysis. Jama Netw. Open 2018, 1, e182327. [CrossRef]

57. Hozumi, Y.; Goto, K. Diacylglycerol kinase $\beta$ in neurons: Functional implications at the synapse and in disease. Adv. Biol. Regul. 2012, 52, 315-325. [CrossRef]

58. Felger, J.C.; Haroon, E.; Patel, T.A.; Goldsmith, D.R.; Wommack, E.C.; Woolwine, B.J.; Le, N.-A.; Feinberg, R.; Tansey, M.G.; Miller, A.H. What does plasma CRP tell us about peripheral and central inflammation in depression? Mol. Psychiatry 2020, 25, 1301-1311. [CrossRef]

59. Loas, G.; Dalleau, E.; Lecointe, H.; Yon, V. Relationships between anhedonia, alexithymia, impulsivity, suicidal ideation, recent suicide attempt, C-reactive protein and serum lipid levels among 122 inpatients with mood or anxious disorders. Psychiatry Res. 2016, 246, 296-302. [CrossRef]

60. Beijers, L.; Wardenaar, K.J.; Bosker, F.J.; Lamers, F.; van Grootheest, G.; de Boer, M.K.; Penninx, B.W.J.H.; Schoevers, R.A. Biomarker-based subtyping of depression and anxiety disorders using Latent Class Analysis. A NESDA study. Psychol. Med. 2019, 49, 617-627. [CrossRef]

61. Baune, B.T.; Smith, E.; Reppermund, S.; Air, T.; Samaras, K.; Lux, O.; Brodaty, H.; Sachdev, P.; Trollor, J.N. Inflammatory biomarkers predict depressive, but not anxiety symptoms during aging: The prospective Sydney Memory and Aging Study. Psychoneuroendocrinology 2012, 37, 1521-1530. [CrossRef] [PubMed]

62. Toker, S.; Shirom, A.; Shapira, I.; Berliner, S.; Melamed, S. The association between burnout, depression, anxiety, and inflammation biomarkers: C-reactive protein and fibrinogen in men and women. J. Occup. Health Psychol. 2005, 10, 344-362. [CrossRef] [PubMed]

63. Maes, M.; Bonifacio, K.L.; Morelli, N.R.; Vargas, H.O.; Moreira, E.G.; St. Stoyanov, D.; Barbosa, D.S.; Carvalho, A.F.; Nunes, S.O.V. Generalized anxiety disorder (GAD) and comorbid major depression with GAD are characterized by enhanced nitro-oxidative stress, increased lipid peroxidation, and lowered lipid-associated antioxidant defenses. Neurotox Res. 2018, 34, 489-510. [CrossRef] [PubMed] 
64. Gammoh, O.S.; Al-Smadi, A.M.; Ashour, A.F.; Al-Awaida, W. Salivary nitric oxide, a biomarker for stress and anxiety? Psychiatry Investig. 2016, 13, 311. [CrossRef] [PubMed]

65. Jin, L.; Qin, L.; Xia, D.; Liu, X.; Fan, Z.; Zhang, C.; Gu, L.; He, J.; Ambudkar, I.S.; Deng, D.; et al. Active secretion and protective effect of salivary nitrate against stress in human volunteers and rats. Free Radic. Biol. Med. 2013, 57, 61-67. [CrossRef]

66. Brites, F.; Martin, M.; Guillas, I.; Kontush, A. Antioxidative activity of high-density lipoprotein (HDL): Mechanistic insights into potential clinical benefit. Bba Clin. 2017, 8, 66-77. [CrossRef]

67. Bulut, M.; Selek, S.; Bez, Y.; Karababa, I.F.; Kaya, M.C.; Gunes, M.; Emhan, A.; Aksoy, N.; Sir, A. Reduced PON1 enzymatic activity and increased lipid hydroperoxide levels that point out oxidative stress in generalized anxiety disorder. J. Affect. Disord. 2013, 150, 829-833. [CrossRef]

68. Shehu, A.; Mohammed, A.; Magaji, R.A.; Muhammad, M.S. Exposure to mobile phone electromagnetic field radiation, ringtone and vibration affects anxiety-like behaviour and oxidative stress biomarkers in albino wistar rats. Metab. Brain Dis. 2016, 31, 355-362. [CrossRef]

69. Bae, Y.J.; Reinelt, J.; Netto, J.; Uhlig, M.; Willenberg, A.; Ceglarek, U.; Villringer, A.; Thiery, J.; Gaebler, M.; Kratzsch, J. Salivary cortisone, as a biomarker for psychosocial stress, is associated with state anxiety and heart rate. Psychoneuroendocrinology 2019, 101, 35-41. [CrossRef] [PubMed]

70. Petrakova, L.; Boy, K.; Mittmann, L.; Möller, L.; Engler, H.; Schedlowski, M. Salivary alpha-amylase and noradrenaline responses to corticotropin-releasing hormone administration in humans. Biol. Psychol. 2017, 127, 34-39. [CrossRef]

71. Jafari, A.; Pouramir, M.; Shirzad, A.; Motallebnejad, M.; Bijani, A.; Moudi, S.; Abolghasem-Zade, F.; Dastan, Z. Evaluation of salivary alpha amylase as a biomarker for dental anxiety. Iran. J. Psychiatry Behav. Sci. 2018, 12, e9350. [CrossRef]

72. Kobayashi, F.Y.; Gavião, M.B.D.; Marquezin, M.C.S.; Fonseca, F.L.A.; Montes, A.B.M.; Barbosa, T.d.S.; Castelo, P.M. Salivary stress biomarkers and anxiety symptoms in children with and without temporomandibular disorders. Braz. Oral Res. 2017, 31. [CrossRef]

73. Dettmer, A.M.; Novak, M.A.; Suomi, S.J.; Meyer, J.S. Physiological and behavioral adaptation to relocation stress in differentially reared rhesus monkeys: Hair cortisol as a biomarker for anxiety-related responses. Psychoneuroendocrinology 2012, 37, 191-199. [CrossRef] [PubMed]

74. Noto, Y.; Sato, T.; Kudo, M.; Kurata, K.; Hirota, K. The relationship between salivary biomarkers and state-trait anxiety inventory score under mental arithmetic stress: A pilot study. Anesth. Analg. 2005, 1873-1876. [CrossRef] [PubMed]

75. Denes, V.; Geck, P.; Mester, A.; Gabriel, R. Pituitary adenylate cyclase-activating polypeptide: 30 years in research spotlight and 600 million years in service. JCM 2019, 8, 1488. [CrossRef] [PubMed]

76. Ross, R.A.; Hoeppner, S.S.; Hellberg, S.N.; O’Day, E.B.; Rosencrans, P.L.; Ressler, K.J.; May, V.; Simon, N.M. Circulating PACAP peptide and PAC1R genotype as possible transdiagnostic biomarkers for anxiety disorders in women: A preliminary study. Neuropsychopharmacology 2020, 45, 1125-1133. [CrossRef] [PubMed]

77. Graham, B.M.; Richardson, R. Memory of fearful events: The role of fibroblast growth factor-2 in fear acquisition and extinction. Neuroscience 2011, 189, 156-169. [CrossRef]

78. Graham, B.M. Fibroblast growth factor-2: A promising biomarker for anxiety and trauma disorders. J. Exp. Neurosci. 2017, 11, 117906951774958. [CrossRef]

79. Veen, G.; Giltay, E.J.; DeRijk, R.H.; van Vliet, I.M.; van Pelt, J.; Zitman, F.G. Salivary cortisol, serum lipids, and adiposity in patients with depressive and anxiety disorders. Metabolism 2009, 58, 821-827. [CrossRef]

80. Yirmiya, K.; Djalovski, A.; Motsan, S.; Zagoory-Sharon, O.; Feldman, R. Stress and immune biomarkers interact with parenting behavior to shape anxiety symptoms in trauma-exposed youth. Psychoneuroendocrinology 2018, 98, 153-160. [CrossRef]

81. Ulmer-Yaniv, A.; Djalovski, A.; Yirmiya, K.; Halevi, G.; Zagoory-Sharon, O.; Feldman, R. Maternal immune and affiliative biomarkers and sensitive parenting mediate the effects of chronic early trauma on child anxiety. Psychol. Med. 2018, 48, 1020-1033. [CrossRef]

82. Hill, M.; Ř́pová, D.; Mohr, P.; Kratochvílová, Z.; Velíková, M.; Dušková, M.; Bičíková, M.; Stárka, L. Circulating C19 steroids and progesterone metabolites in women with acute depression and anxiety disorders. Horm. Mol. Biol. Clin. Investig. 2016, 26, 153-164. [CrossRef]

83. Dušková, M.; Hill, M.; Bičíková, M.; Šrámková, M.; Řípová, D.; Mohr, P.; Stárka, L. The steroid metabolome in men with mood and anxiety disorders. Physiol. Res. 2015, 64, S275-S282. [CrossRef] 
84. Hill, M.; Dušková, M.; Stárka, L. Dehydroepiandrosterone, its metabolites and ion channels. J. Steroid Biochem. Mol. Biol. 2015, 145, 293-314. [CrossRef] [PubMed]

85. Jung, Y.-H.; Kim, H.; Jeon, S.Y.; Kwon, J.M.; Lee, W.J.; Jang, J.H.; Lee, D.; Lee, Y.; Kang, D.-H. Peripheral and central metabolites affecting depression, anxiety, suicidal ideation, and anger in complex regional pain syndrome patients using a magnetic resonance spectroscopy: A pilot study. Psychiatry Investig. 2018, 15, 891-899. [CrossRef] [PubMed]

86. Taylor, R.; Osuch, E.A.; Schaefer, B.; Rajakumar, N.; Neufeld, R.W.J.; Théberge, J.; Williamson, P.C. Neurometabolic abnormalities in schizophrenia and depression observed with magnetic resonance spectroscopy at 7 T. Bjpsych Open 2017, 3, 6-11. [CrossRef]

87. Jollant, F.; Near, J.; Turecki, G.; Richard-Devantoy, S. Spectroscopy markers of suicidal risk and mental pain in depressed patients. Prog. Neuro-Psychopharmacol. Biol. Psychiatry 2017, 73, 64-71. [CrossRef] [PubMed]

88. Crespo, I.; Santos, A.; Gómez-Ansón, B.; López-Mourelo, O.; Pires, P.; Vives-Gilabert, Y.; Webb, S.M.; Resmini, E. Brain metabolite abnormalities in ventromedial prefrontal cortex are related to duration of hypercortisolism and anxiety in patients with Cushing's syndrome. Endocrine 2016, 53, 848-856. [CrossRef]

89. Yüksel, C.; Öngür, D. Magnetic resonance spectroscopy studies of glutamate-related abnormalities in mood disorders. Biol. Psychiatry 2010, 68, 785-794. [CrossRef]

90. Hammen, T.; Kuzniecky, R. Magnetic resonance spectroscopy in epilepsy. In Handbook of Clinical Neurology; Elsevier: Amsterdam, The Netherlands, 2012; Volume 107, pp. 399-408. ISBN 978-0-444-52898-8.

91. Miranda, D.; Anatriello, E.; Azevedo, L.; Santos, J.; Cordeiro, J.F.; Peria, F.; Floria-Santos, M.; Pereira-Da-Silva, G. Fractalkine (C-X3-C motif chemokine ligand 1) as a potential biomarker for depression and anxiety in colorectal cancer patients. Biom. Rep. 2017, 7, 188-192. [CrossRef]

92. Wada, A.; Ito, A.; Iitsuka, H.; Tsuneyama, K.; Miyazono, T.; Murakami, J.; Shibahara, N.; Sakurai, H.; Saiki, I.; Nakayama, T.; et al. Role of chemokine CX3CL1 in progression of multiple myeloma via CX3CR1 in bone microenvironments. Oncol. Rep. 2015, 33, 2935-2939. [CrossRef]

93. Rogers, J.T.; Morganti, J.M.; Bachstetter, A.D.; Hudson, C.E.; Peters, M.M.; Grimmig, B.A.; Weeber, E.J.; Bickford, P.C.; Gemma, C. CX3CR1 deficiency leads to impairment of hippocampal cognitive function and synaptic plasticity. J. Neurosci. 2011, 31, 16241-16250. [CrossRef]

94. Shan, B.; Ai, Z.; Zeng, S.; Song, Y.; Song, J.; Zeng, Q.; Liao, Z.; Wang, T.; Huang, C.; Su, D. Gut microbiome-derived lactate promotes to anxiety-like behaviors through GPR81 receptor-mediated lipid metabolism pathway. Psychoneuroendocrinology 2020, 117, 104699. [CrossRef] [PubMed]

95. Clarke, G.; Grenham, S.; Scully, P.; Fitzgerald, P.; Moloney, R.D.; Shanahan, F.; Dinan, T.G.; Cryan, J.F. The microbiome-gut-brain axis during early life regulates the hippocampal serotonergic system in a sex-dependent manner. Mol. Psychiatry 2013, 18, 666-673. [CrossRef] [PubMed]

96. Davis, D.J.; Hecht, P.M.; Jasarevic, E.; Beversdorf, D.Q.; Will, M.J.; Fritsche, K.; Gillespie, C.H. Sex-specific effects of docosahexaenoic acid (DHA) on the microbiome and behavior of socially-isolated mice. Brain Behav. Immun. 2017, 59, 38-48. [CrossRef]

97. Stevens, B.R.; Goel, R.; Seungbum, K.; Richards, E.M.; Holbert, R.C.; Pepine, C.J.; Raizada, M.K. Increased human intestinal barrier permeability plasma biomarkers zonulin and FABP2 correlated with plasma LPS and altered gut microbiome in anxiety or depression. Gut 2018, 67, 1555-1557. [CrossRef]

98. Liu, R.T. The microbiome as a novel paradigm in studying stress and mental health. Am. Psychol. 2017, 72, 655-667. [CrossRef] [PubMed]

99. Queiroz, M.P.; da Silva Lima, M.; de Melo, M.F.F.T.; Bertozzo, C.C.d.M.S.; de Araújo, D.F.; Guerra, G.C.B.; Queiroga, R.d.C.R.d.E.; Soares, J.K.B. Maternal suppplementation with conjugated linoleic acid reduce anxiety and lipid peroxidation in the offspring brain. J. Affect. Disord. 2019, 243, 75-82. [CrossRef]

100. Guedine, C.R.d.C.; Pordeus, L.C.d.M.; Riul, T.R.; Jordão, A.A.; Almeida, S.S. Cafeteria diet during lactation and/or post-lactation altered lipid profile/lipid peroxidation and increased anxiety-like behavior in male rat offspring. Nutr. Neurosci. 2018, 23,1-11. [CrossRef]

101. Trujillo, J.; Vieira, M.C.; Lepsch, J.; Rebelo, F.; Poston, L.; Pasupathy, D.; Kac, G. A systematic review of the associations between maternal nutritional biomarkers and depression and/or anxiety during pregnancy and postpartum. J. Affect. Disord. 2018, 232, 185-203. [CrossRef]

102. Verly-Miguel, M.V.B.; Farias, D.R.; Pinto, T.d.J.P.; Lepsch, J.; Nardi, A.E.; Kac, G. Serum docosahexaenoic acid (DHA) is inversely associated with anxiety disorders in early pregnancy. J. Anxiety Disord. 2015, 30, 34-40. [CrossRef] [PubMed] 
103. Grimes, S.B.; Wild, R. Effect of pregnancy on lipid metabolism and lipoprotein levels. In Endotext [Internet]; MDText.com, Inc.: South Dartmouth, MA, USA, 2018.

104. Troisi, A.; Moles, A.; Panepuccia, L.; Lo Russo, D.; Palla, G.; Scucchi, S. Serum cholesterol levels and mood symptoms in the postpartum period. Psychiatry Res. 2002, 109, 213-219. [CrossRef]

105. Maes, M.; Claes, M.; Schotte, C.; Delbeke, L.; Jacquemyn, Y.; Verkerk, R.; De Meester, I.; Scharpé, S. Disturbances in dexamethasone suppression test and lower availability of Ł-tryptophan and tyrosine in early puerperium and in women under contraceptive therapy. J. Psychosom. Res. 1992, 36, 191-197. [CrossRef]

106. Maes, M.; Ombelet, W.; Verkerk, R.; Bosmans, E.; Scharpé, S. Effects of pregnancy and delivery on the availability of plasma tryptophan to the brain: Relationships to delivery-induced immune activation and early post-partum anxiety and depression. Psychol. Med. 2001, 31, 847-858. [CrossRef] [PubMed]

107. Huang, J.Y.; Arnold, D.; Qiu, C.; Miller, R.S.; Williams, M.A.; Enquobahrie, D.A. Association of serum vitamin D with symptoms of depression and anxiety in early pregnancy. J. Women's Health 2014, 23, 588-595. [CrossRef] [PubMed]

108. Roomruangwong, C.; Kanchanatawan, B.; Sirivichayakul, S.; Mahieu, B.; Nowak, G.; Maes, M. Lower serum iinc and higher CRP strongly predict prenatal depression and physio-somatic symptoms, which all together predict postnatal depressive symptoms. Mol. Neurobiol. 2017, 54, 1500-1512. [CrossRef] [PubMed]

109. Gancheva, S.; Galunska, B.; Zhelyazkova-Savova, M. Diets rich in saturated fat and fructose induce anxiety and depression-like behaviours in the rat: Is there a role for lipid peroxidation? Int. J. Exp. Path. 2017, 98, 296-306. [CrossRef] [PubMed]

110. Ganji, A.; Salehi, I.; Sarihi, A.; Shahidi, S.; Komaki, A. Effects of Hypericum Scabrum extract on anxiety and oxidative stress biomarkers in rats fed a long-term high-fat diet. Metab. Brain Dis. 2017, 32, 503-511. [CrossRef] [PubMed]

111. Abshirini, M.; Siassi, F.; Koohdani, F.; Qorbani, M.; Mozaffari, H.; Aslani, Z.; Soleymani, M.; Entezarian, M.; Sotoudeh, G. Dietary total antioxidant capacity is inversely associated with depression, anxiety and some oxidative stress biomarkers in postmenopausal women: A cross-sectional study. Ann. Gen. Psychiatry 2019, 18, 3. [CrossRef]

112. Sánchez-Montoya, E.L.; Reyes, M.A.; Pardo, J.; Nuñez-Alarcón, J.; Ortiz, J.G.; Jorge, J.C.; Bórquez, J.; Mocan, A.; Simirgiotis, M.J. High resolution UHPLC-MS metabolomics and sedative-anxiolytic effects of Latua pubiflora: A mystic plant used by Mapuche Amerindians. Front. Pharm. 2017, 8, 494. [CrossRef]

113. Tokumo, K.; Tamura, N.; Hirai, T.; Nishio, H. Effects of (Z)-3-hexenol, a major component of green odor, on anxiety-related behavior of the mouse in an elevated plus-maze test and biogenic amines and their metabolites in the brain. Behav. Brain Res. 2006, 166, 247-252. [CrossRef]

114. Davydova, A.I.; Klodt, P.M.; Kudrin, V.S.; Kuznetsova, E.A.; Narkevich, V.B. Neurochemical study of effects of the new anxiolytic drugs Afobazol and Ladasten on the synthesis and metabolism of monoamines and their metabolites in the brain structures of wistar rat on the model of monoamine synthesis blockade induced by aromatic amino acid decarboxylase inhibitor NSD-1015. Eksp. Klin. Farmakol. 2010, 73, 2-6.

115. Schousboe, A. Metabolic signaling in the brain and the role of astrocytes in control of glutamate and GABA neurotransmission. Neurosci. Lett. 2019, 689, 11-13. [CrossRef] [PubMed]

116. Bergink, V. Glutamate and anxiety. Eur. Neuropsychopharmacol. 2004, 14, 175-183. [CrossRef]

117. Matés, J. Glutamine and its relationship with intracellular redox status, oxidative stress and cell proliferation/death. Int. J. Biochem. Cell Biol. 2002, 34, 439-458. [CrossRef]

118. Otify, A.; George, C.; Elsayed, A.; Farag, M.A. Mechanistic evidence of Passiflora edulis (Passifloraceae) anxiolytic activity in relation to its metabolite fingerprint as revealed via LC-MS and chemometrics. Food Funct. 2015, 6, 3807-3817. [CrossRef] [PubMed]

119. Aponso, M.; Patti, A.; Bennett, L.E. Dose-related effects of inhaled essential oils on behavioural measures of anxiety and depression and biomarkers of oxidative stress. J. Ethnopharmacol. 2020, 250, 112469. [CrossRef]

120. Novío, S.; Núñez, M.J.; Ponte, C.M.; Freire-Garabal, M. Urinary biopyrrins: Potential biomarker for monitoring of the response to treatment with anxiolytics. Basic Clin. Pharm. Toxicol. 2012, 111, 206-210. [CrossRef]

121. Matsumoto, K.; Yobimoto, K.; Huong, N.T.T.; Abdel-Fattah, M.; Van Hien, T.; Watanabe, H. Psychological stress-induced enhancement of brain lipid peroxidation via nitric oxide systems and its modulation by anxiolytic and anxiogenic drugs in mice. Brain Res. 1999, 839, 74-84. [CrossRef] 
122. Machado, K.d.C.; Oliveira, G.L.d.S.; Islam, M.T.; de Almeida, A.A.C.; Junior, A.L.G.; Machado, K.d.C.; de Sousa, D.P.; Melo-Cavalcante, A.A.d.C.; de Freitas, R.M. Effects of isopentyl ferulate on oxidative stress biomarkers and a possible GABAergic anxiolytic-like trait in Swiss mice. Chem. Biol. Interact. 2018, 289, 119-128. [CrossRef]

123. Cruz, J.N.d.; Magro, D.D.D.; Lima, D.D.d.; Cruz, J.G.P. Simvastatin treatment reduces the cholesterol content of membrane/lipid rafts, implicating the N-methyl-D-aspartate receptor in anxiety: A literature review. Braz. J. Pharm. Sci. 2017, 53, e16102. [CrossRef]

124. Liu, X.; Zhu, W.; Guan, S.; Feng, R.; Zhang, H.; Liu, Q.; Sun, P.; Lin, D.; Zhang, N.; Shen, J. Metabolomic analysis of anti-hypoxia and anti-anxiety effects of Fu Fang Jin Jing oral liquid. PLOS ONE 2013, 8, e78281. [CrossRef]

125. Khlebnikova, N.N.; Kushnareva, E.Y.; Kudrin, V.S.; Krupina, N.A. The effects of imipramine and the inhibitor of prolylendopeptidase benzyloxycarbonyl-methionyl-2(S)-cyanopyrrolidine on the levels of monoamines and their metabolites in the brain of rats with an experimental anxious-depressive state. Neurochem. J. 2014, 8, 271-276. [CrossRef]

126. Hone-Blanchet, A.; Mondino, M.; Fecteau, S. Repetitive transcranial magnetic stimulation reduces anxiety symptoms, drug cravings, and elevates 1 H-MRS brain metabolites: A case report. Brain Stimul. 2017, 10, 856-858. [CrossRef] [PubMed]

127. Wu, A.; Ying, Z.; Gomez-Pinilla, F. Docosahexaenoic acid dietary supplementation enhances the effects of exercise on synaptic plasticity and cognition. Neuroscience 2008, 155, 751-759. [CrossRef] [PubMed]

128. van Praag, H. Exercise Enhances Learning and Hippocampal Neurogenesis in Aged Mice. J. Neurosci. 2005, 25, 8680-8685. [CrossRef]

129. Santos-Soto, I.J.; Chorna, N.; Carballeira, N.M.; Vélez-Bartolomei, J.G.; Méndez-Merced, A.T.; Chornyy, A.P.; de Ortiz, S.P. Voluntary running in young adult mice reduces anxiety-like behavior and increases the accumulation of bioactive lipids in the cerebral cortex. PLoS ONE 2013, 8, e81459. [CrossRef] [PubMed]

130. Kunutsor, S.K.; Seidu, S.; Blom, A.W.; Khunti, K.; Laukkanen, J.A. Serum C-reactive protein increases the risk of venous thromboembolism: A prospective study and meta-analysis of published prospective evidence. Eur. J. Epidemiol. 2017, 32, 657-667. [CrossRef]

131. Khorvash, M.; Askari, A.; Rafiemanzelat, F.; Botshekan, M.; Khorvash, F. An investigation on the effect of strength and endurance training on depression, anxiety, and C-reactive protein's inflammatory biomarker changes. J. Res. Med. Sci. 2012, 17, 1072-1076.

132. Liu, L.-Y.; Zhang, H.-J.; Luo, L.-Y.; Pu, J.-B.; Liang, W.-Q.; Zhu, C.-Q.; Li, Y.-P.; Wang, P.-R.; Zhang, Y.-Y.; Yang, C.-Y.; et al. Blood and urinary metabolomic evidence validating traditional Chinese medicine diagnostic classification of major depressive disorder. Chin. Med. 2018, 13, 53. [CrossRef]

133. Paredes, R.M.; Quinones, M.; Marballi, K.; Gao, X.; Valdez, C.; Ahuja, S.S.; Velligan, D.; Walss-Bass, C. Metabolomic profiling of schizophrenia patients at risk for metabolic syndrome. Int. J. Neuropsychopharm. 2014, 17, 1139-1148. [CrossRef]

134. Davison, J.; O'Gorman, A.; Brennan, L.; Cotter, D.R. A systematic review of metabolite biomarkers of schizophrenia. Schizophr. Res. 2018, 195, 32-50. [CrossRef]

135. Czysz, A.H.; South, C.; Gadad, B.S.; Arning, E.; Soyombo, A.; Bottiglieri, T.; Trivedi, M.H. Can targeted metabolomics predict depression recovery? Results from the CO-MED trial. Transl. Psychiatry 2019, 9, 1-11. [CrossRef] [PubMed]

136. Bhattacharyya, S.; Dunlop, B.W.; Mahmoudiandehkordi, S.; Ahmed, A.T.; Louie, G.; Frye, M.A.; Weinshilboum, R.M.; Krishnan, R.R.; Rush, A.J.; Mayberg, H.S.; et al. Pilot study of metabolomic clusters as state markers of major depression and outcomes to CBT treatment. Front. Neurosci. 2019, 13, 926. [CrossRef] [PubMed]

(C) 2020 by the authors. Licensee MDPI, Basel, Switzerland. This article is an open access article distributed under the terms and conditions of the Creative Commons Attribution (CC BY) license (http://creativecommons.org/licenses/by/4.0/). 